\title{
PROSEDUR PENGELOLAAN SURAT \\ UNTUK MEMPERLANCAR PROSES PENYAMPAIAN INFORMASI PADA KANTOR KECAMATAN PAMULANG
}

\author{
Oleh: Drs. H.M. Sugeng Hidayat, MM \& Umi Jumiatin
}

\begin{abstract}
Abstrak
Organisasi dalam pencapaian tujuan ada kalanya jauh dari yang diharapkan, tetapi ada kalanya diakhiri dengan hasil yang optimal. Hal ini tergantung dari administrasi yang dijalankan oleh tiap-tiap perusahaan. Agar pelaksanaan kegiatan kantor dapat berjalan dengan baik diperlukannya administrasi perkantoran. Disini adalah rangkaian aktivitas perkantoran yang mencakup perencanaan, pengorganisasian, pengarahan, pengawasan, pengendalian serta penyelenggaraan pekerjaan kantor. Pekerjaan kantor ini berkenaan dengan pembuatan surat, penyampaian keterangan, laporan-laporan dan pengarsipan. Tata usaha adalah segenap aktivitas menghimpun, mencatat, mengolah, mengirim dan menyimpan keterangan-keterangan yang diperlukan dalam setiap organisasi. Administrasi, organisasi dan manajemen yang modern itu hanya dapat terwujud apabila manusia sebagai pelaksananya berpikiran modern dan maju atau disebut juga manusia modern. Manusia modern adalah merka yang sadar dan berusaha meningkatkan mutu hidupnya. Oleh sebab itu dalam kesempatan pengamatan yang di laksanakan kali ini, akan dipaparkan prosedur pengelolaan surat yang diharapkan dapat memperlancar proses penyampaian informasi, khususnya dalam kepengurusan ketatausahaan organisasi instansi pemerintah yang makin hari makin dituntut kelancaran administrasinya guna menunjang keefektifan kinerja dan terpenuhinya kebutuhan masyarakat.
\end{abstract}

\section{PENDAHULUAN}

\section{Latar Belakang}

Pada era globalisasi dewasa ini, dimana dunia terasa semakin sempit karena kemajuan teknologi, terutama di bidang informasi, komunikasi dan teknologi, terlihat tuntutan tugas bagi semua pihak yang semakin meningkat dan semakin berat.

Proses pelaksanaan administrasi dapat dipercepat dan dipertepat serta praktis dengan memanfaatkan kemajuan ilmu pengetahuan dan teknologi tersebut, disamping dengan menggunakan cara kerja yang sesuai dengan prinsip-prinsip administrasi, organisasi dan manajemen yang modern.

Ilmu Office Management adalah ilmu yang sangat penting dipelajari dan dipahami. Ilmu Office Management itu sangat besar manfaatnya terutama bagi pimpinan dalam suatu 
ada kalanya diakhiri dengan hasil yang optimal. Hal ini tergantung dari administrasi yang dijalankan oleh tiap-tiap perusahaan. Agar pelaksanaan kegiatan kantor dapat berjalan dengan baik diperlukannya administrasi perkantoran. Disini adalah rangkaian aktivitas perkantoran yang mencakup perencanaan, pengorganisasian, pengarahan, pengawasan, pengendalian serta penyelenggaraan pekerjaan kantor. Pekerjaan kantor ini berkenaan dengan pembuatan surat, penyampaian keterangan, laporan-laporan dan pengarsipan. Tata usaha adalah segenap aktivitas menghimpun, mencatat, mengolah, mengirim dan menyimpan keterangan-keterangan yang diperlukan dalam setiap organisasi. Administrasi, organisasi dan manajemen yang modern itu hanya dapat terwujud apabila manusia sebagai pelaksananya berpikiran modern dan maju atau disebut juga manusia modern. Manusia modern adalah merka yang sadar dan berusaha meningkatkan mutu hidupnya. Oleh sebab itu dalam kesempatan pengamatan yang di laksanakan kali ini, akan dipaparkan prosedur pengelolaan surat yang diharapkan dapat memperlancar proses penyampaian informasi, khususnya dalam kepengurusan ketatausahaan organisasi instansi pemerintah yang makin hari makin dituntut kelancaran administrasinya guna menunjang keefektifan kinerja dan terpenuhinya kebutuhan masyarakat.

\section{PENDAHULUAN}

\section{Latar Belakang}

Pada era globalisasi dewasa ini, dimana dunia terasa semakin sempit karena kemajuan teknologi, terutama di bidang informasi, komunikasi dan teknologi, terlihat tuntutan tugas bagi semua pihak yang semakin meningkat dan semakin berat.

Proses pelaksanaan administrasi dapat dipercepat dan dipertepat serta praktis dengan memanfaatkan kemajuan ilmu pengetahuan dan teknologi tersebut, disamping dengan menggunakan cara kerja yang sesuai dengan prinsip-prinsip administrasi, organisasi dan manajemen yang modern.

Ilmu Office Management adalah ilmu yang sangat penting dipelajari dan dipahami. Ilmu Office Management itu sangat besar manfaatnya terutama bagi pimpinan dalam suatu kantor atau instansi. Seperti kita ketahui bahwa kantor merupakan tempat berkumpulnya para pegawai yang melakukan kegiatan-kegiatan dalam kantor. Oleh karena itu kantor akan menjadi penting bagi suatu organisasi, karena administrasi kantor dilaksanakan di dalam kantor. Ketertiban dan kelancaran merupakan faktor penting dalam kepengurusan administrasi. Salah satu tugas tata usaha dari pengertian administrasi diatas berkaitan 
dengan keterangan, surat menyurat dan warkat-warkat, sering disebut pekerjaan tulis menulis yang kemudian terkumpul menjadi arsip.

Prosedur pengelolaan surat perlu diterapkan untuk masing-masing unit organisasi, karena merupakan sumber data atau informasi yang bermanfaat untuk kemajuan organissi tersebut secara maksimal. Surat adalah alat komunikasi tertulis yang berasal dari satu pihak dan ditujukan kepada pihak lain untuk menyampaikan warta (Bartos, 2003:36). Seiring dengan berkembangnya zaman, teknologi komunikasi berkembang begitu pesat dengan banyak bermunculnya berbagai alat telekomunikasi atau penghubung yang canggih seperti, telepon, handphone, televisi, radio, telepon, faximile dan sebagainya. Namun masih ada komunikasi tertulis yang tidak dapat dilupakan keberadaannya bahkan masih tetap kokoh terpakai seolah tak bisa tergantikan oleh berbagai peralatan komunikasi yang canggih itu, komunikasi tertulis tersebut adalah surat.

Surat adalah sehelai kertas atau lebih yang digunakan untuk mengadakan komuniksi secara tertulis (Silmi, 2002 :1). Surat masih digunakan sampai sekarang karena surat masi memiliki kelebihan dibandingkan dengan sarana komunikasi lainnya. Kelebihan tersebut karena surat lebih praktis, efektif dan ekonomis. Surat selain berfungsi sebagai alat komunikasi juga berfungsi sebagai alat pengingat, bahan bukti hitam diatas putih yang memiliki kekuatan hukum,sumber data, alat pengingat, jaminan, duta atau wakil dan surat juga berfungsi sebagai alat untuk promosi.

Dalam suatu organisasi atau perusahaan surat menurut prosedur pengurusannya dibagi menjadi dua yaitu surat masuk dan surat keluar. Surat masuk adalah semua jenis surat yang diterima dari instansi lain maupun perorangan, baik yang diterima melalui pos maupun yang diterima melalui kurir dengan mempergunkan buku pengiriman atau ekspedisi. Sedangkan surat keluar adalah surat yang sudah lengkap (bertanggal,bernomor,berstempel,dan telah ditandatangani oleh pejaat yang berwenang) yang dibuat oleh suatu instansi, kantor atau lembaga untuk diajukan atau dikirim kepada instansi, kantor atau lembaga lain (Wursanto, 2013 : 104).

Prosedur pengelolaan surat masuk yang meliputi, pengelompokkan surat, membuka surat, pemeriksaan surat, pencatatan surat dan pendistribusian surat. Sedangkan untuk pengelolaan surat keluar meliputi, pembuatan konsep, persetujuan konsep, pengetikan surat, pemberian nomor, penyusunan surat, pengiriman surat (Widjaja, 2002 : $30)$.

Pengelolaan surat pada Kantor Kecamatan Pamulang Kota Tangerang Selatan yaitu ada pada Bagian Umum dan Kepegawaian. Bagian Umum dan Kepegawaian pada 
Kantor Kecamatan Pamulang adalah bagian yang mengurusi kegiatan administrasi termasuk mengurusi jalannya surat masuk dan surat keluar. Pengelolaan surat dalam penelitian ini yaitu suatu proses atau kegiatan dalam suatu organisasi dalam pencapaian tujuan dengan menggunakan sumber daya yang ada dimulai dari kegiatan penerimaan, pencatatan, penyimpanan, peminjaman, penyusutan samapai dengan kegiatan pemusnahan surat. Pengelolaan surat sendiri terdiri dari pengelolaan surat masuk dan surat keluar.

Pengolahan surat masuk dan surat keluar adalah pekerjaan surat menyurat yang harus dilakukan secara tertata dan berurutan dengan kegiatan yang utama yaitu mengelola, mengatur, dan mengurus surat menyurat agar dapat memperlancar administrasi intansi tersebut. Apabila pengurusan surat masuk dan surat keluar pada suatu instansi atau kantor dapat dilakukan dengan baik dan tersusun secara rapi maka penyebaran informasi kepada bagian-bagain lain yang bersangkutan tidak mengalami kendala dan juga akan memudahkan dalam penemuan kembali arsip apabila suatu saat diperlukan.

Dilihat dari prosedur pengurusan surat menurut Amin (2005), surat menyurat atau korespondensi dalam organisasi pemerintah atau swasta terbagi menjadi dua kelompok yaitu korespondensi eksternal (surat keluar) dan korespondensi internal (surat masuk). Di dalam pengelolaan surat dapat dilakukan dengan menggunakan tiga sistem, yaitu sistem buku agenda, lembar disposisi, dan buku register. Dalam penanganan surat setiap kantor tidak akan mungkin sama. Hal ini dipengaruhi oleh frekuensi kegiatan atau besar kecilnya kantor tersebut juga prosedur, tata cara dan bentuk perlengkapan yang dipergunakan.

Setelah melalui proses pengadministrasian surat, selanjutnya dilakukan proses pengarsipan. Fungsi dari pengarsipan sendiri adalah untuk dapat menemukan kembali arsip secara cepat, sehingga apabila diperlukan dapat cepat untuk ditemukan.

Apabila penanganan surat tersebut berjalan sesuai dengan yang telah ditetapkan sebelumnya tujuan organisasi akan cepat tercapai. Karena surat merupakan bahan informasi yang utama bagi suatu instansi aatau kantor itu sendiri. Apabila penanganan surat tidak baik tidak menutup kemungkinan penyebaran informasi akan terhamabat dan tujuan organisasi akan sulit untuk tercapai. Menurut observasi yang dilakukan di Kantor Kecamatan Pamulang bahwa seluruh kegiatan surat menyurat yang meliputi surat masuk dan surat keluar hanya ditangani oleh satu orang pegawai. Selain itu cara penanganan suratnya pun cukup sederhana, yaitu pencatatan surat masih bergantung pada buku agenda saja. 
Meskipun demikian Kantor Kecamatan Pamulang tetap mampu melayani kebutuhan masyarakat dengan baik. Misalnya dapat membuat dan mengirim surat keluar dengan cepat dan tepat tujuan, mampu melaksanakan pangadaan dokumen yang dibutuhkan masyarakat dengan cepat, dan lain sebagainya. Namun dalam kenyataanya Kantor Kecamatan Pamulang masih mengalami beberapa kendala dalam pengelolaan surat masuk dan surat keluar. Adapun kendala-kendala yang muncul dalam pengelolaan surat masuk dan keluar seperti terkadang tidak semua surat diserahkan ke petugas pengelola surat untuk diarsipkan, tetapi masih disimpan di masing-masing bidang yang berkepentingan atau tujuan dari surat tersebut. Sehingga petugas hanya mengarsip surat yang didisposisi dan diserahkan ke petugas pengelola surat saja. Terkadang petugas lupa memberi nomor surat keluar, dan ada juga alamat tujuan yang salah, dan terkadang ada pegawai yang meminjam surat dan pada waktu pengembalian surat tersebut pegawai yang meminjam surat itu mengembalikan surat sendiri tanpa memberi tahu petugas pengelola surat dan terjadi kesalahan tempat dalam mengembalikan surat. Sehingga pada waktu surat diperlukan kembali surat tersebut susah diketemukan. Hal ini menjadi wajar terjadi karena dari sekian surat yang masuk setiap hari pada bagian umum yang merupakan pintu masuk bagi semua surat yang diterima Kantor Kecamatan Pamulang Kota Tangerang Selatan hanya dikerjakan oleh seorang karyawan bidang kearsipan jumlah ini dirasa kurang dengan melihat jumlah surat yang masuk setiap harinya. Setidaknya ada dua orang pegawai yang bertugas menangani pengurusan surat mauk dan keluar, sehingga akan memudahkan dalam penyebaran informasi kesemua bagian-bagian yang bersangkutan.

Penanganan surat merupakan hal yang sangat penting terlebih pada organisasi pemerintahan seperti Kantor Kecamatan yang berhubungan dengan banyak instansi maupun orang perorangan yang membutuhkan informasi dari Kantor Kecamatan tersebut. Penanganan surat yang baik akan memudahakan pihak-pihak yang berhubungan untuk mengakses informasi yang diperlukannya.

Dari latar belakang di atas dapat diketahui mengenai pentingnya peranan surat menyurat dalam suatu organisasi / instansi dan cara pengelolaannya, maka penulis tertarik mengambil judul "Prosedur Pengelolaan Surat Untuk Memperlancar Proses Penyampaian Informasi Pada Kantor Kecamatan Pamulang"

\section{Identifikasi Masalah}

Berdasarkan Latar Belakang masalah tersebut di atas, penulis mengidentifikasikan masalah, sebagai berikut: 
1. Pelaksanaan pengelolaan surat di kantor kecamatan Pamulang belum maksimal.

2. Pegawai/petugas yang menangani surat belum mempunyai keahlian

khusus dalam bidang surat menyurat.

3. Masih banyak surat yang belum disimpan dengan baik.

4. Penataan surat belum dilakukan secara maksimal

\section{Pembatasan Masalah}

Agar lebih fokus pada penulisan laporan ini, maka penulis membatasi masalah sesuai dengan pengetahuan yang didapat selama melaksanakan Praktik Kerja Lapangan di Kantor Kecamatan Pamulang, Tangerang Selatan. Penulis akan membuat laporan mengenai "Prosedur Penanganan Surat Untuk Memperlancar Proses Penyampaian Informasi pada Kantor Kecamatan Pamulang”.

\section{Perumusan Masalah}

Berdasarkan pembatasan masalah di atas, maka tugas akhir ini dirumuskan sebagai berikut:

1. Bagaimana pelaksanaan pengelolaan surat masuk pada Kantor Kecamtan Pamulang?

2. Bagaimana pelaksanaan pengelolaan suratkeluar pada Kantor Kecamatan Pamulang?

3. Bagaimana cara mengarsip surat pada Kantor Kecamatan Pamulang?

4. Kendala-kendala apa saja yang terjadi pada saat pengelolaan surat?

Kecamatan Pamulang?

\section{Tujuan dan Manfaat}

Tujuan diadakan praktik kerja lapangan dengan maksud :

1. Menumbuhkan kesadaran betapa pentingnya pengetahuan tentang administrasi terutama mengenai penganganan surat.

2. Memahami alur pengurusan surat masuk dan keluar pada suatu organisasi.

3. Mengetahui prosedur pengelolaan surat yang digunakan pada Kantor Kecamatan Pamulang.

\section{Manfaat}

1. Bagi Penulis

Tugas akhir ini diharapkan dapat meningkatkan pengetahuan penulis tentang Imu pengetahuan di bidang Administrasi Perkantoran mengenai pengelolaan surat dan 
dapat memenuhi syarat kelulusan Program Diploma Tiga (D. III) Jurusan Ekonomi Sekretaris di Universitas Pamulang.

2. Bagi Pembaca

Penulis berharap tugas akhir ini dapat dijadikan sebagai bahan referensi bagi pembaca serta dapat dijadikan bahan perbandingan bagi perusahaan lain.

3. Bagi Perusahaan

Penulis berharap tugas akhir ini dapat memberikan kontribusi bagi perusahaan sebagai bahan pertimbangan dan perbandingan dengan perusahaan lain dan dapat memberikan sumbangan pemikiran bagi kantor dan bahan pertimbangan dalam pengelolaan surat masuk dan surat keluar di Kantor Kecamatan Pamulang.

\section{Metode Pengumpulan Data}

Penulisan laporan tugas akhir yang dibuat oleh penulis menggunakan metode pengumpulan data terlebih dahulu. Pengumpulan data yang digunakan sebagai berikut:

1. Metode Observasi

Pengumpulan data yang dilakukan dengan pengamatan langsung di mana penulis mengadakan praktik kerja dan mengamati secara langsung dalam pelaksanaan kegiataan pengelolaan surat masuk dan surat keluar pada kasi Umum dan Kepegawaian di Kantor Kecamatan Pamulang.

2. Metode study pustaka

Pengumpulan data dengan cara membaca beberapa buku tentang prosedur pengelolaan surat masuk dan surat keluar yang tersedia di perpustakaan dan book store yang berhubungan degan materi laporan tugas akhir ini.

\section{LANDASAN TEORI}

\section{Pengerrtian Surat}

Manusia merupakan makhluk sosial yang saling membutuhkan. Karena saling membutuhkan, maka mereka secara otomatis akan saling interaksi. Dalam proses interaksi tentunya mereka melakukan suatu komunikasi dengan surat menyurat.

Surat juga dapat menjadi buku tertulis atau arsip sehingga penulisannya harus di susun dengan baik, teliti, dan efesien. Untuk itu, kita harus mengusai kaidah-kaidah bahasa yang baik dan benar. Dari kaidah-kaidah bahasa tersebut kita harus mengetahui tentang 
pengertian surat. Adapun pendapat mengenai pengertian surat menurut para ahli ialah: menurut Sedarmayanti, surat adalah alat komunikasi tertulis yang berasal dari satu pihak ditujukan kepada pihak lain untuk menyampaikan warta.(2005:26).

Sedangkan menurut Y.S. Marjo dalam bukunya surat menyurat lengkap mempunyai pengertian lain bahwa: Surat adalah komunikasi tertulis atau sarana untuk menyampaikan pernyataan maupun informasi secara tertulis dari pihak satu kepada pihak yang lain (2005:15).

Dari pendapat di atas mengenai surat, ada lagi pendapat menurut Thomas Wiyasa pengertian surat yaitu: Surat adalah sarana untuk menyampaikan pernyataan atau informasi secara tertulis dari pihak yang satu ke pihak yang lain, informasi dapat berupa pemberitahuan, pernyataan laporan, pemikiran, sanggahan dan lain sebagainya (1996:2). dan menurut Moekijat Surat adalah kertas sehelai atau lebih di mana di tuliskan suatu pernyataan atau berita sesuatu yang hendak orang nyatakan pada orang lain (2006:5).

Sedangkan menurut Suhanda Panji surat adalah sehelai kertas / lebih yang memuat suatu bahan komunikasi yang di sampaikan oleh seseorang kepada orang lain baik atas mana pribadi maupun kedutaan dalam organisasi. (1997:38).

Ada juga pendapat yang di ungkapkan menurut Atmo Sudirjo mengenai surat adalah sehelai kertas yang di tulis atau di ketik atas nama dalam kedudukan yang di tujukan kepada suatu alamat tertentu dan membuat suatu badan komunikasi. (1999:139).

Sedangkan menurut The Liang Gie, surat adalah setiap cacatan tertulis atau bergambar yang memuat keterangan mengenai suatu hal atau peristiwa yang di buat orang untuk membantu ingatannya. (2000:115).

Pendapat yang berbeda di ungkapkan menurut Tedja Sutisna yaitu surat adalah alat komunikasi untuk menyampaikan pernyataan / informasi secara tertulis dari pihak yang satu kepada pihak yang lain (1999:82). Sedangkan menurut Rizal, surat adalah alat untuk menyampaikan suatu maksud secara tertulis, baik tentang penawaran, permintaan, pernyataan, pertanyaan, lamaran pekerjaan, dan lain-lain. (2003:2). dan menurut Bratawidjaja mengunkapkan bahwa surat adalah sarana untuk menyampaikan pernyataan atau informasi secara tertulis dari pihak satu ke pihak lain, informasi itu dapat berupa pemberitahuan, pertanyaan, pernyataan, permintaan, laporan, pemikiran, sanggahan dan sebagainya. (1982:5). 
Sedangkan pendapat menurut Wursanto yaitu: surat adalah salah satu alat penyampaian informasi atau keterangan-keterangan (keputusan, pernyataan, permintaan, dan sebagainya) secara tertulis dari pihak satu ke pihak lainnya. (1991:11). Menurut Pratama, surat adalah satu alat untuk menyampaikan informasi / suatu pernyataan secara tertulis kepada pihak lain, baik itu atas nama sendiri, jabatan yang di sondang dari suatu instansi perusahaan / organisasi. (1997:1).

Lain halnya dengan yang di kemukakan menurut Mansur, surat adalah sehelai kertas / lebih yang di tulis / di ketik dengan menggunakan susunan kalimat dalam bahasa yang baik dan benar dan biasanya berisi curahan hati atau berita yang di sampaikan dari jarak jauh dari seseorang ke orang lain. (1986:11).

Dari pendapat-pendapat para ahli di atas, penulis menyimpulkan bahwa surat merupakan bukti tertulis dan menjadi suatu alat komunikasi / informasi yang kita sampaikan sesuai dengan tujuan yang kita harapkan, maka kita harus mengusahakan agar isi surat mudah di mengerti dan disusun dengan baik teliti dan efisien.

Surat merupakan lembaran kertas yang ditulis atas nama pribadi penulis, atau atas nama kedudukannya dalam organisasi untuk berbagai kepentingan. pengertian lain dari surat adalah alat komunikasi tertulis untuk menyampaikan isi hati atau maksud kepada orang lain (perseorangan atau organisasi).

Surat juga dapat diartikan sebagai suatu sarana komunikasi yang digunakan untuk menyampaikan informasi tertulis oleh suatu pihak kepada pihak lain atas nama perseorangan dan dapat atas nama jabatan dalam suatu organisasi. Kegiatan saling berkirim surat oleh perseorangan atau oleh organisasi di sebut surat menyurat atau korespondensi, dan pihak yang terlibat atau para pelakunya di sebut dengan koresponden.

\section{Macam- macam surat}

Dalam kehidupan sehari-hari terdapat bermacam-macam jenis surat yang beredar, baik wujud, tujuan, isi, jumlah penerima, keamanan isinya, urgensi penyelesaian, sumber dan pengelolaannya. Menurut Barthos (2009 : 37-39) jika diklasifikasikan maka surat dapat dibedakan dalam berbagai hal seperti dibawah ini :

1. Menurut wujudnya

Menurut wujudnya surat dapat dibedakan menjadi beberapa macam antara lain :

a). Kartu pos 
Kartu pos adalah wujud surat terbuka yang terbuat dari karton berukuran $10 \times 15 \mathrm{~cm}$. Kartu pos dipergunakan untuk menyampaikan berita pendek yang isinya dapat diketahui orang lain.

b). Warkat pos

Warkat pos adalah wujud surat yang tertutup yang terbuat dari sehelai kertas yang telah dicetak, dapat dilipat seperti amplop. Warkat pos dipergunakan untuk menyampaikan berita pendek yang isinya dapat diketahui orang lain.

c). Surat bersampul

Surat bersampul adalah wujud surat tertutup yang memakai sampul. Surat bersampul digunakan untuk :

1) Menyampaikan berita yang isinya tidak dapat diketahui orang lain.

2) Mengirim berita yang isinya lebih panjang daripada warkat pos, dan lebih menghormati pihak yang dikirimi berita.

d). Memorandum dan Nota

Morandum adalah surat yang berisi catatan singkat tentang pokok- pokok persoalan. Memo dibuat oleh atasan untuk bawahan atau sebaliknya. Nota adalah surat yang hanya dibuat oleh atasan untuk bawahannya. Pada dasarnya isi nota sama dengan isi surat dinas, hanya lebih ringkas tetapi jelas.

e). Telegram

Telegram adalah surat yang susunannya ringkas dan jelas dengan bahasa yang jelas yang memuat berita-berita yang penting saja yang dituliskan, dan penulisannya menggunakan huruf morse.

\section{Menurut isinya}

Menurut isinya dapat digolongkan menjadi :

a). Surat dinas

Surat dinas adalah surat yang berisi masalah kedinasan atau administrasi pemerintah. Surat dinas dibuat oleh instansi pemerintah dan dikirim kepada semua pihak yang memiliki hubungan dengan instansi tersebut, karena surat dinas sifatnya resmi, maka surat tersebut ditulis menggunakan bahasa ragam resmi. Contoh surat dinas diantaranya adalah surat keputusan, instruksi, surat tugas, surat edaran, surat panggilan, nota dinas, pengumuman dan surat undangan rapat dinas.

b). Surat niaga 
Surat niaga adalah surat yang berisi masalah perniagaan. Surat niaga dibuat oleh suatu perusahaan yang ditujukan kepada semua pihak. Contoh surat niaga diantaranya adalah surat pesanan, surat tagihan, surat permohonan lelang dan periklanan.

c). Surat pribadi

Surat pribadi adalah surat yang berisi masalah pribadi yang ditujukan kepada keluarga, teman atau kenalan. Karena surat pribadi sifatnya akrab, maka menggunakan bahasa yang santai dan luwes untuk menambah rasa kekeluargaan atau persahabatan.

3. Menurut jumlah penerima

Dilihat dari jumlah penerima surat, maka surat dapat dibedakan menjadi beberapa macam antara lain :

a). Surat biasa

Surat biasa adalah surat yang khusus ditujukan kepada seorang pejabat, atau instansi tertentu.

b). Surat edaran

Surat edaran adalah surat yang dibuat oleh instansi luar. Isi surat ini adakalanya hanya ditujukan kepada pejabat tertentu yang bersangkutan (edaran khusus), dan adakalanya disebarkan kepada lingkungan yang luas (edaran umum).

c). Surat pengumuman

Surat pengumuman adalah surat yang ditujukan kepada para pejabat, karyawan dan masyarakat umum.

4. Menurut keamanan isinya

Dilihat dari keamanan isinya surat dapat dibedakan menjadi beberapa macam antara lain :

a). Surat sangat rahasia

Surat sangat rahasia adalah surat yang berisi dokumen atau naskah yang sangat penting yang berhubungan dengan rahasia keamanan negara ataupun rahasia pribadi seseorang. Surat seperti ini berhubungan erat dengan keamanan negara, dan biasanya diberi tanda "RHS" atau "SR".

b). Surat rahasia

Surat rahasia adalah surat yang berisi dokumen penting yang hanya diketahui oleh pejabat yang berhak menerimanya.

c). Surat biasa 
Surat biasa adalah surat yang berisi masalah umum dan biasa, bukan rahasia, yang bila diketahui orang lain tidak merugikan lembaga atau pejabat yang bersangkutan.

5. Menurut urgensi penyelesaian

Berdasarkan urgensi pengiriman surat dapat dikelompokkan menjadi :

a). Surat Sangat Segera (Kilat)

Surat sangat segera (kilat) adalah surat yang isinya harus sesegera mungkin diketahui oleh penerima surat dan harus sesegera mungkin diselesaikan atau ditanggapi. Penyelesaian surat ini harus lebih diprioritaskan daripada surat lainnya. Jadi, surat sangat segera harus diutamakan penyelesainnya.

b). Surat Segera

Surat segera adalah surat yang harus segera diketahui dan ditanggapi. Penyelesaian surat ini tidak harus dilakukan pada kesempatan pertama tetapi disesuaikan dengan pedoman yang berlaku pada instansi yang bersangkutan.

c). Surat Biasa

Surat biasa adalah surat yang isinya tidak harus segera diketahui dan ditanggapi. Meskipun demikian, surat yang diterima harus segera dibalas agar komunikasi dapat berjalan dengan lancar.

6. Menurut prosedur pengurusan

Menurut prosedur pengurusannya surat digolongkan menjadi :

a). Surat Masuk

Surat masuk adalah suatu alat komunikasi tertulis untuk menyampaikan pesan atau informasi dari satu pihak kepada pihak yang lain.

b). Surat Keluar

Surat keluar adalah surat yang lengkap (bertanggal, bernomor, berstempel dan ditandatangani oleh pejabat yang berwenang) yang dibuat oleh suatu instansi atau lembaga lain. Surat keluar biasanya dikirim melalui pos atau kurir.

7. Menurut jangkauannya

Menurut jangkauannya surat digolongkan menjadi :

a). Surat Intern

Surat intern adalah surat yang hanya digunakan untuk berkomunikasi dalam suatu kantor atau instansi yang bersangkutan.

b). Surat Ekstern

Surat ekstern adalah surat yang digunakan untuk berkomunikasi dengan pihakpihak diluar kantor instansi yang bersangkutan 


\section{Fungsi dan kedudukan surat dalam kinerja kantor}

Setiap organisasi atau lembaga pasti memiliki pengelolaan surat menyurat yang berbeda-beda. Surat yang dimiliki dapat menyangkut kelangsungan hidup organisasi dan mempunyai kepentingan bagi organisasi. Karena pentingnya surat maka penyimpanannya akan dilakukan secara teratur dalam suatu tempat sehingga setiap akan diperlukan dapat ditemukan kembali dengan cepat dan tepat. Surat tersebut harus disimpan dengan baik karena mempunyai fungsi dan nilai kegunaan didalamnya. Selain sebagai sarana atau wahana komunikasi surat juga mempunyai fungsi antara lain :

1. Menurut Barthos (2009 : 36) surat mempunyai fungsi sebagai berikut:
a). Wakil dari pengirim atau penulis.
b). Bahan Pembukti.
c). Pedoman dalam mengambil tindakan lebih lanjut.
d). Alat pengukur kegiatan organisasi.
e). Sarana memperpendek jarak (fungsi abstrak).

2. Sedangkan fungsi surat menurut Silmi (2008 : 2-3) antara lain:

a). Surat berfungsi sebagai sarana komunikasi, surat merupakan sarana komunikasi yang ekonomis, efektif dan praktis.

b). Wakil, surat menjadi wakil dari pembuat surat yang membawa pesan, misi atau informasi yang hendak disampaikan kepada penerima.

c). Bahan bukti, mengingat surat merupakan sarana komunikasi secara tertulis, maka surat dapat dijadikan bahan bukti yang mempunyai kekuatan hukum.

d). Sumber data, surat dapat menjadi sumber data yang dapat digunakan untuk informasi atau petunjuk keterangan untuk di tindak lanjuti.

e). Bahan pengingat, Surat mengingatkan seseorang dalam kegiatan atau aktifitasnya dimasa lalu yang bisa dipergunakan untuk melakukan kegiatan selanjutnya baginya.

f). Jaminan, Surat dapat menjadi surat jaminan, seperti jaminan keamanan pada surat jalan, jaminan tanggungan pada surat gadai dan lain sebagainya.

g). Alat pengikat, Surat dapat digunakan untuk mengikat antara dua pihak dengan kekutan hukum, semisal dalam surat kontrak.

h). Alat promosi, Surat dapat menjadi alat promosi bagi biro, kantor atau perusahaan pengirim surat kepada penerima surat atau siapapun juga yang membaca surat tersebut.

i). Alat untuk penghematan, Surat dapat menghemat, baik waktu, tenaga dan juga biaya, karena selembar surat telah dapat mewakili kedatangan pembuat surat secara nyata. 
Dari fungsi surat diatas dapat diketahui kedudukan surat dalam kinerja kantor meliputi sebagai berikut :

1. Surat mempunyai kedudukan sebagai wakil dari pengirim atau penulis.

2. Surat berkedudukan sebagai pedoman dalam mengambil tindakan lebih lanjut.

3. Surat berkedudukan sebagai jaminan.

\section{Prinsip-prinsip surat}

Menurut Moekijat (2001 : 52) ada empat prinsip yang akan memungkinkan dalam menulis sepucuk surat agar memberikan kesan yang baik dan pada waktu bersamaan menyampaikan arti yang sebenarnya mengenai apa yang ingin dikatakan, keempat prinsip tersebut meliputi :

1. Keringkasan, ini berarti bahwa surat harus pendek, walaupun ada beberapa surat yang panjang akan tetapi adalah masih mungkin menggunakan jumlah kata yang sedikitdikitnya untuk menyatakan arti yang penulis ingin sampaikan.

2. Kejelasan, tidak boleh ada arti dua, misal, kata " apakah yang dimaksud ini apa itu ?" maka surat tersebut dikatakan tidak jelas.

3. Kesederhanaan, dalam pembuatan surat kata-kata yang sedehana akan memberikan arti yang lebih jelas daripada menggunakan kata-kata yang panjang dan sulit.

4. Kesopanan, pembuatan surat dengan penyusunan kalimat yang bijaksana, suatu pendekatan yang menyenangkan dan penulisan yang lancar membentuk nada surat.

\section{Prosedur pengelolaan surat masuk dan surat keluar}

\section{Pengertian Prosedur}

Prosedur menurut Moekijat (2001 : 194) adalah suatu rangkaian tugas-tugas yang saling berhubungan yang merupakan urutan-urutan menurut waktu dan tatacara tertentu untuk melaksanakan suatu pekerjaan yang harus diselesaikan, prosedur merupakan bagian penting dalam tiap perusahaan. Menurut Zulkifli (2005 : 51) prosedur adalah langkahlangkah atau kegiatan yang mempunyai urutan untuk menyelesaikan pekerjaan yang bersangkutan. Prosedur adalah suatu rangkaian metode yang telah menjadi pola tetap dalam melakukan suatu pekerjaan yang merupakan suatu kebulatan. (The Liang Gie, 2003: 187) Menurut pendapat beberapa ahli di atas maka dapat disimpulkan bahwa prosedur adalah suatu tatacara kerja atau kegiatan untuk menyelesaikan pekerjaan dengan urutan waktu dan memiliki pola kerja yang telah ditentukan.

2. Pengertian Pengelolaan 
Pengelolaan adalah proses yang membantu merumuskan kebijakan dan tujuan organisasi atau proses yang memberikan pengawasan pada semua hal yang terlibat dalam pelaksanaan kebijaksanaan dan pencapaian tujuan. (Poerwadarminta, $2006: 88$ ) Pengelolaan adalah proses, cara, perbuatan pengelolaan yang membantu merumuskan kebijakan dan tujuan organisasi atau yang memberikan pengawasan suatu hal yang terlibat dalam pelaksanaan kebijakan dan pencapaian tujuan dengan menggunakan tenaga orang lain. (Ibnu syamsi, $2008: 8$ ).

Pengelolaan adalah suatu proses yang membantu merumuskan kebijaksanaan dan tujuan organisasi atau proses yang memberikan pengawasan pada semua hal yang terlibat dalam pelaksanaan kebijaksanaan dan pencapaian tujuan. (Tim Penyusun KBBI, 2002 : 534) Menurut pendapat beberapa ahli di atas maka dapat disimpulkan bahwa pengelolaan adalah suatu proses dalam menjalankan suatu pekerjaan untuk mencapai tujuan tertentu.

\section{Pengertian Surat}

Menurut Atmosudirdjo (2001 : 139) surat adalah sehelai kertas yang ditulis (pada waktu ini umumnya diketik) atas nama pribadi penulis, atau atas nama kedudukanya dalam organisasi, yang ditujukan pada suatu alamat tertentu dan memuat sesuatu “ bahan komunikasi “. Surat menurut Barthos (2009 : 36) adalah alat komunikasi tertulis yang berasal dari satu pihak dan ditujukan kepada pihak lain untuk menyampaikan warta. Sedangkan pengertian surat menurut Silmi (2008: 1) adalah sehelai kertas atau lebih yang digunakan untuk mengadakan komunikasi secara tertulis. Menurut Rahardi (2008: 12) surat adalah pernyataan tertulis dari pihak satu kepihak lain, atas nama perseorangan ataupun atas nama jabatan.

Dari beberapa pendapat diatas maka dapat disimpulkan mengenai pengertian surat yaitu sarana atau wahana komunikasi tertulis yang ditujukan kepada orang lain atau suatu instansi dengan tujuan untuk menyampaikan suatu hal baik itu berupa informasi, perintah atau sebuah pemberitahuan. Surat masuk adalah semua jenis surat yang diterima dari instansi lain maupun perorangan, baik yang diterima melalui pos, maupun yang diterima dari kurir dengan mempergunakan buku pengiriman. Surat keluar adalah surat yang lengkap (bertanggal, bernomor, berstempel dan ditandatangani oleh pejabat yang berwenang) yang dibuat oleh suatu instansi atau lembaga lain. Surat keluar biasanya dikirim melalui pos atau kurir. Dari pengertian-pengertian di atas dapat disimpulkan bahwa prosedur pengelolaan surat masuk dan surat keluar adalah pekerjaan surat-menyurat yang harus dilakukan secara tertata dan berurutan dengan 
kegiatan utama yaitu mengelola, mengatur dan mengurus surat-menyurat agar dapat memperlancar administrasi instansi tersebut.

Dalam pengelolaan surat dapat diselenggarakan dengan dua cara yaitu :

a. Buku agenda

Menurut Agus Sugiarto (2005 : 27) pencatatan dengan buku agenda dilakukan oleh instansi yang belum menerapkan sistem kartu kendali. Pencatatan surat masuk dan surat keluar dapat dipisahkan dengan menggunakan buku agenda surat masuk dan buku agenda surat keluar, yang biasanya dibedakan tahunnya.

1) Buku agenda tunggal

Buku agenda tunggal adalah buku yang digunakan untuk mencatat surat masuk dan surat keluar sekaligus berurutan pada tiap-tiap halaman.

2) Buku agenda berpasangan

Buku agenda berpasangan adalah buku yang dipergunakan untuk mencatat surat masuk dihalaman kiri dan surat keluar pada halaman kanan dengan nomor surat sendiri.

3) Buku agenda kembar

Buku agenda kembar adalah buku yang digunakan untuk mencatat surat masuk dan surat keluar sendiri.

\section{b. Kartu kendali}

Menurut Sudarmayanti (2003 : 85) pengurusan dengan menggunakan kartu kendali disebut dengan sistem kearsipan pola baru. Kartu kendali adalah helai tipis berukuran $10 \times 15 \mathrm{~cm}$ berisi kolom-kolom untuk mencatat surat masuk dan surat keluar serta untuk mengendalikan surat tersebut. Kartu kendali berfungsi sebagai pengganti buku agenda, yang mana penggunaannya dapat ditulis rangkap dua, rangkap tiga atau rangkap empat, sesuai dengan kebutuhan masing-masing kantor. Menurut Wursanto (2003 : 110-128) prosedur pengelolaan surat masuk dan surat keluar melalui beberapa tahapan, yaitu:

\section{Pengelolaan Surat Masuk}

Dalam pengelolaan surat masuk diperlukan langkah-langkah yang baik dan sistematis. Adapun pengelolaan surat masuk adalah sebagai berikut:

a). Penerimaan 
Surat pertama kali diterima atau diambil dari kurir yang mengantar surat tersebut. Tugas penerima adalah:

1. Mengumpulkan dan menghitung jumlah surat yang masuk,

2. Meneliti ketepatan alamat si pengirim surat,

3. Menggolongkan surat sesuai dengan urgensi penyelesaian,

4. Menandatangani bukti pengiriman sebagai tanda surat telah diterima.

b). Penyortiran

Penyortiran dapat dilakukan berdasarkan atas golongan surat biasa, rutin dan rahasia. Penyortiran adalah kegiatan memisah-misahkan surat untuk pengolahan lebih lanjut.

c). Pencatatan

Setelah surat dicatat, distempel (dicap) serta memeriksa ketepatan jenis ataupun jumlah lampiran yang harus diterima maka langkah berikutnya adalah melakukan pencatatan.

d). Mengagendakan surat masuk

Mengagendakan surat masuk adalah kegiatan mencatat surat masuk dan surat keluar kedalam buku agenda (buku harian). Setiap surat yang masuk dicatat dan diberi nomor agenda surat masuk.

e). Pengarahan dan penerusan

Surat-surat yang perlu diproses lebih lanjut, harus diarahkan dan diteruskan kepada pejabat yang berhak mengolahnya.

f). Penyampaian surat

Penyampaian surat dilakukan oleh petugas pengarah yang dilaksanakan dengan langkah-langkah sebagai berikut :

1. Surat yang sudah didisposisi terlebih dahulu dicatat dalam buku agenda.

2. Menyampaikan surat terlebih dahulu melalui buku agenda yang bersangkutan.

3. Petugas pengarah mengembalikan kepada petugas untuk dicatat dalam buku pengarahan.

g). Penggandaan

Penggandaan surat dapat dilakukan dengan mesin fotokopi.

h). Penyimpanan berkas atau arsip surat masuk 
Penyimpanan berkas atau arsip surat dari pimpinan dilakukan oleh unit pengolah dengan mempergunakan metode kearsipan yang berlaku pada instansi tersebut.

Untuk lebih jelasnya, berikut ini Arus atau Tata aliran Pengelolaan Surat Masuk

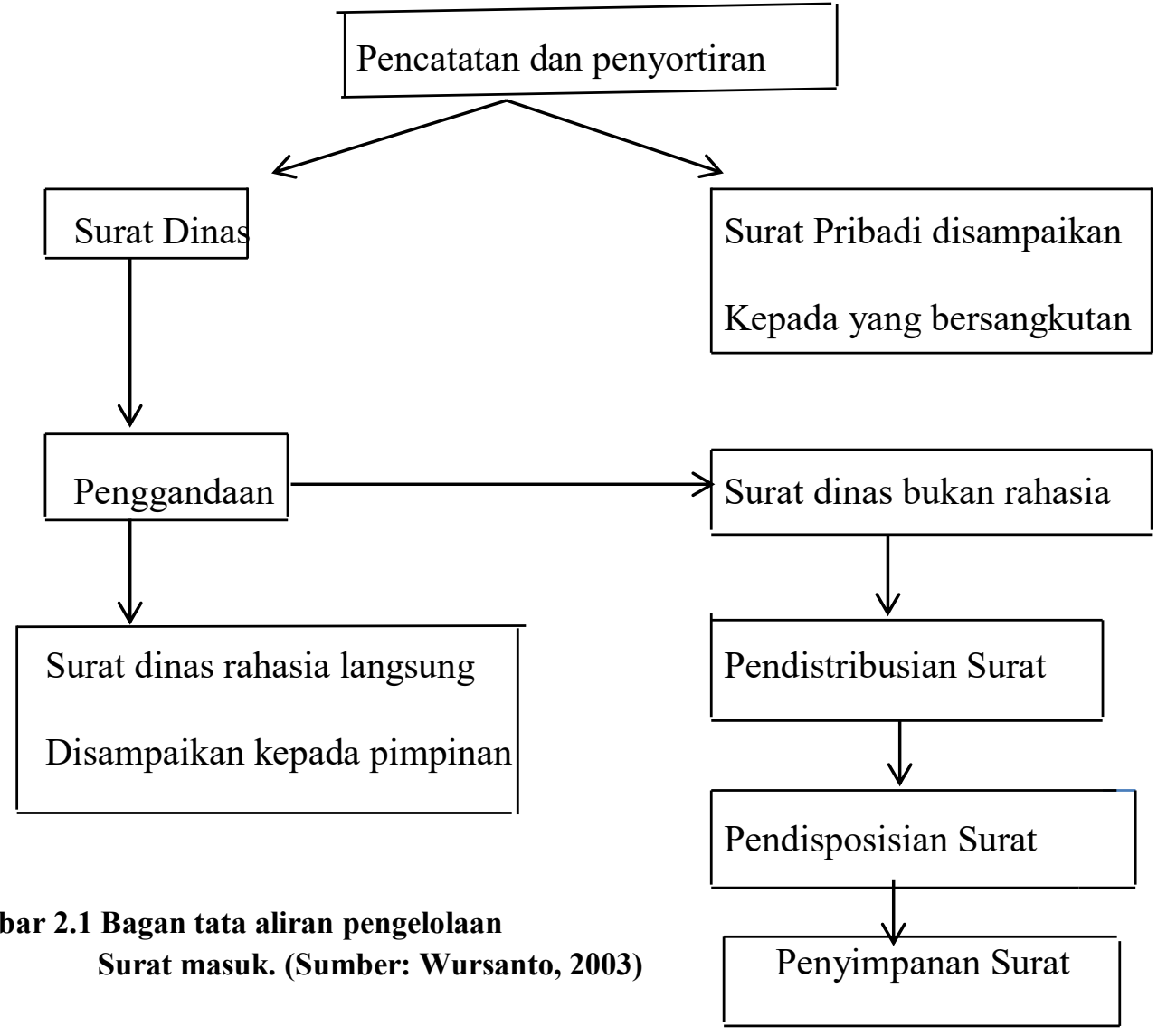

\section{Keterangan gambar Penyimpanan Surat}

1. Setelah surat masuk diterima oleh petugas penerima selanjutnya akan dipilah menjadi 2 macam, yaitu :

a. Surat pribadi dapat langsung ditujukan kepada yang bersangkutan.

b. Surat dinas dapat dibedakan antara surat sangat rahasia/rahasia dan bukan rahasia, kemudian diserahkan kepada Agendaris.

2. Selanjutnya oleh Agendaris surat yang sifatnya rahasia akan langsung disampaikan kepada pimpinan dan untuk surat yang sifatnya bukan rahasia oleh Agendaris dibuka. Selanjutnya Agendaris akan membaca isi suratnya terus dicatat pada buku agenda.

3. Kemudian surat akan dibaca oleh pimpinan untuk didiposisi. Biasanya disposisi dibubuhkan di bagian kiri bawah yang kosong atau bagian kiri atas sebelum salam pembuka. Disposisi berupa: alamat disposisi, isi disposisi, paraf dan tanggal 
disposisi. Selesai didisposisi oleh pimpinan, surat akan disalurkan ke alamat disposisi (biasanya Kepala Bagian).

4. Kepala bagian (alamat disposisi) setelah membaca isi surat akan memproses surat tersebut sesuai dengan disposisi yang dibubuhkan pimpinan. Apabila surat telah selesai diolah, Kepala Bagian akan membubuhkan disposisi di bawah disposisi yang telah ada. Selanjutnya surat diserahkan kepada Arsiparis.

5. Selanjutnya Arsiparis mencatat surat pada buku arsip sesuai dengan pokok soal.

\section{Pengelolaan Surat Keluar}

Prosedur pengelolaan surat keluar yang baik hendaknya menggunakan langkah-langkah sebagai berikut :

a. Pembuatan konsep surat

Konsep surat disebut juga dengan istilah draft. Konsep surat disusun dan dibuat sesuai bentuk surat yang benar atau yang dikehendaki pimpinan.

b. Pengetikan

Apabila konsep surat telah mendapat persetujuan dan memperoleh kode atau nomor surat, diserahkan kepada unit pengolah. Kemudian kepala unit pengolah harus tekun dan teliti dalam memeriksa hasil pengetikan konsep surat tersebut hingga konsep surat tersebut menjadi bentuk surat yang sesuai dengan ketentuan yang ada, setelah melalui koreksi kesalahan.

c. Mengetik surat dalam bentuk akhir

Konsep yang telah disetujui pimpinan kemudian diketik dalam bentuk akhir pada kertas berkepala surat atau kop surat.

d. Penandatanganan

Surat itu kemudian disampaikan kepada pimpinan, atau pejabat yang berewenang untuk menandatangani.

e. Pencatatan

Dalam pencatatan ini kegiatan-kegiatan yang dilakukan yaitu sebagai berikut:

1) Surat yang telah ditandatangani, dicap disertai kelengkapan lainnya, seperti lampiran dan amplop.

2) Surat dinas resmi ini lebih dulu dicatat dalam agenda oleh petugas yang disebut agendaris. 
3) Surat dinas telah selesai dicatat dalam buku agenda, kemudian surat tersebut siap untuk dikirim.

\section{f. Pengiriman surat}

Pengiriman surat dapat dilakukan dengan dua macam cara yaitu dikirim secara langsung atau melalui pos.

g. Penyimpanan surat

Lembar utama dikirim ke alamat yang dituju, sedangkan lembar kedua disimpan dengan menggunakan sistem kearsipan yang dipakai oleh suatu organisasi.

Berikut ini Arus atau Tata aliran Pengelolaan Surat Keluar

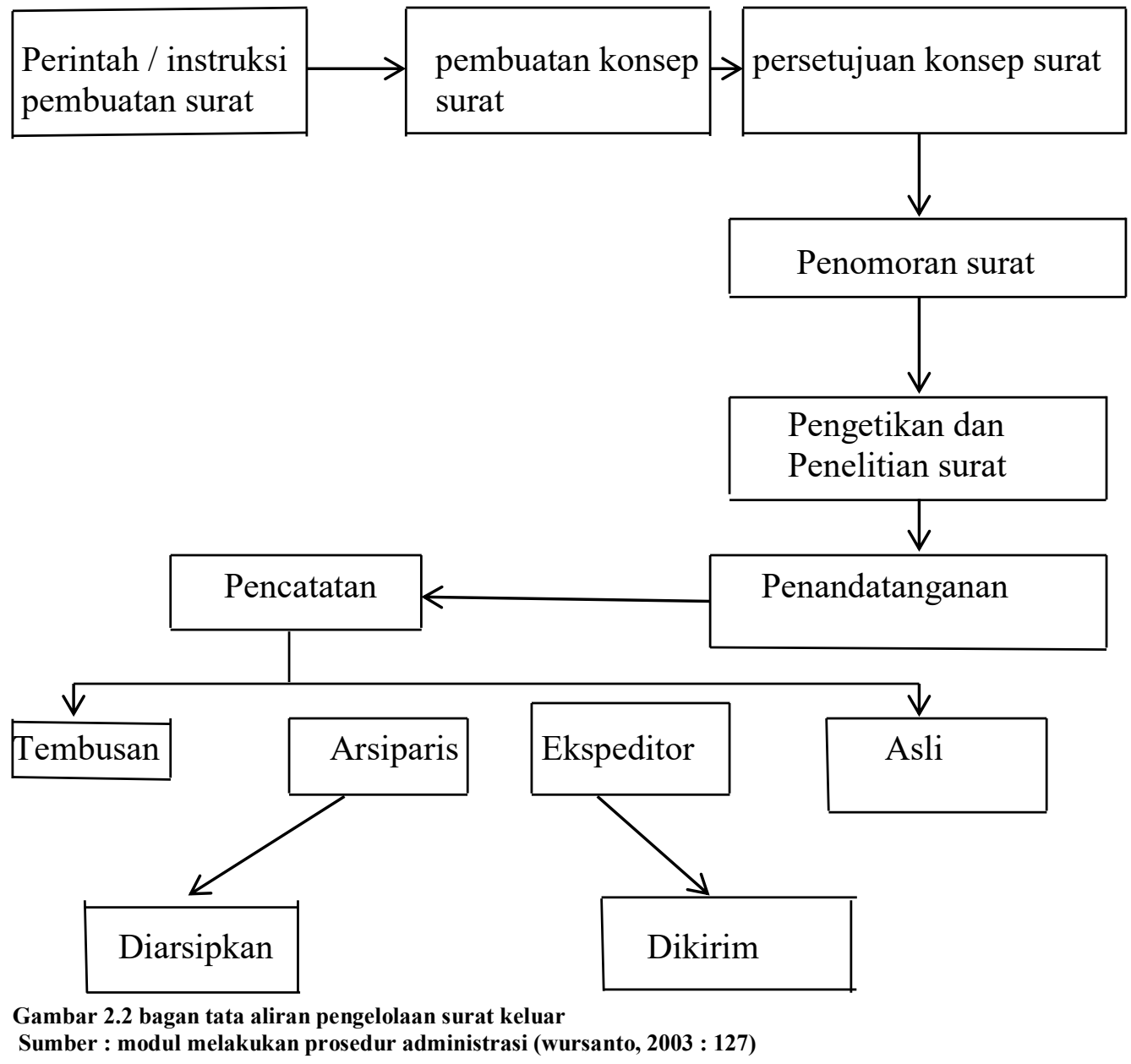

$\underline{\text { Keterangan gambar Surat Keluar }}$

1. Pembuatan surat diawali dengan adanya perintah atau instruksi dari pimpinan kepada Unit Pengolah.

2. Unit Pengolah kemudian membuat konsep surat. 
3. Konsep surat kemudian diserahkan kepada pimpinan untuk mendapatkan persetujuan.

4. Konsep surat yang sudah disetujui oleh pimpinan kemudian diserahkan ke bagian Verbalis untuk mendapatkan nomor surat.

5. Konsep surat diserahkan kepada juru tik dan siap untuk diketik.

6. Tugas juru ketik kemudian adalah:

a. Mengetik konsep tersebut rangkap dua (satu untuk dikirim dan satu untuk diarsipkan)

b. Setelah selesai pengetikan, juru tik membubuhkan paraf pada lembar konsep, dan

c. Menyerahkan naskah surat kepada Sekretaris atau Kepala Tata Usaha untuk dicocokkan dengan konsep surat.

Apabila naskah surat tidak sama dengan konsep maka naskah akan dikembalikan kepada juru tik untuk diketik ulang, tetapi apabila naskah surat sudah sesuai dengan surat maka Sekretaris dan Kepala Tata Usaha akan membubuhkan paraf kecil sebagai tanda penelitian (tanda taklik) di sebelah kiri atas bagian tanda tangan.

7. Naskah surat kemudian diserahkan kepada pimpinan yang memberikan instruksi untuk ditandatangani

8. Setelah ditandatangani, surat asli dan tembusan diserahkan ke bagian Verbalis untuk dicatat di buku verbal atau buku agenda. Surat keluar kemudian dicap dan diperiksa kelengkapannya seperti lampiran dan sampul surat. Surat asli diserahkan ke bagian ekspedisi, sedangkan tembusan diserahkan ke bagian arsip.

9. Surat asli oleh ekspeditur dicatat dalam buku ekspedisi kemudian dilipat dan dimasukkan ke dalam sampul surat.

10. Tembusan surat oleh Arsiparis dicatat dalam buku arsip kemudian diarsipkan menggunakan sistem kearsipan yang dipergunakan di kantor tersebut.

\section{Peralatan dan Perlengkapan Pengelolaan Surat}

Dalam penanganan surat diperlukan alat-alat sebagai berikut :

\section{Kartu kendali}

Kartu kendali merupakan alat yang berfungsi untuk menelusuri dan mengendalikan proses pengelolaan surat-surat dinas. Kartu kendali dapat digunakan sebagai pengganti dari buku agenda, karena dengan menggunakan buku agenda justru akan mempersulit 
dalam penemuan informasi suatu surat secara cepat. Kartu kendali yaitu prosedur pencatatan dan pengendalian surat sehingga surat dapat dikontrol sejak masuk sampai disimpan. (Zulkifli Amsyah, 2005 : 57)

Kartu kendali dapat digunakan untuk mendapatkan informasi suatu surat agar lebih mudah dibanding dengan buku agenda. Sebab kartu kendali disusun sistematis didalam kotak, sedangkan buku agenda susunannya kronologis.

2. Lembar disposisi

Lembar disposisi adalah lembaran untuk menuliskan disposisi suatu surat baik yang diberikan oleh atasan kebawahan maupun sebaliknya. (Basir Barthos, 2009 : 5) Lembar disposisi digunakan untuk mencatat pendapat singkat dari pimpinan mengenai suatu surat. Oleh sebab itu surat tidak perlu digandakan walaupun pemrosesan surat melalui lebih dari satu unit kerja. Lembar disposisi disiapkan oleh petugas tata usaha pada satuan kerja pengarah dan pimpinan tinggal mengisi kolom isi disposisi serta penerusannya kepada pejabat siapa. Lembar disposisi dibuat dengan ukuran setengah kuarto.

3. Folder

Folder adalah semacam map tetapi tidak dengan daun penutup. Pada folder terdapat tab yaitu bagian yang menonjol pada sisi atas untuk menempatkan titel file yang bersangkutan. Lipatan pada dasar folder dibuat sedemikian rupa sehingga dapat membuat daya muat dokumen. Pada umumnya folder terbuat dari kertas manila, panjang $35 \mathrm{~cm}$, lebar $24 \mathrm{~cm}$, tabnya berukuran panjang $8-9 \mathrm{~cm}$, lebar $2 \mathrm{~cm}$. Folder diisi dengan (tempat memasukkan) dokumen atau arsip hingga merupakan bagian terkecil dalam klasifikasi suatu masalah. (Bartos Bashir, 2009 : 198) .

4. Guide (penunjuk atau pemisah)

Guide merupakan penunjuk tempat berkas-berkas itu disimpan, sekaligus berfungsi sebagai pemsah antara berkas-berkas tersebut. Guide berbentuk segi panjang dan terbuat dari kertas setebal $1 \mathrm{~cm}$, dengan panjang 33-35 $\mathrm{cm}$ dan tinggi $23-24 \mathrm{~cm}$. Guide mempunyai tab (bagian yang menonjol) diatasnya yang berguna untuk menempatkan atau mencantumkan kode klasifikasi dan disusun secara berdiri. (Basir Barthos, 2009 :199)

5. Tickler file (berkas pengingat)

Alat ini semacam kotak dipergunakan untuk menyimpan kartu kendali atau kartu pinjam arsip. (Basir Barthos, 2009 : 200)

6. Filling cabinet (lemari arsip) 
Filling cabinet dipergunakan untuk menyimpan folder yang telah berisi lembaranlembaran arsip bersama guide-guidenya. Filling cabinet berlaci empat dan terbuat dari logam yang kuat, tahan air, tahan panas serta praktis. (Basir Barthos, 2009 : 201)

7. Buku agenda

Buku agenda berisi kolom-kolom keterangan (data) dari surat yang dicatat. Buku agenda juga digunakan sebagai alat bantu untuk mencari surat yang disimpan di file dan merupakan referensi pertama untuk mencari surat.

\section{PEMBAHASAN DAN HASIL}

\section{Gambaran Umum Objek Penelitian}

Kecamatan Pamulang kota Tangerang Selatan merupakan Lembaga atau instansi Pemerintahan yang merupakan unsur Penyelenggara Pemerintah Daerah, sesuai yang disebutkan dalam pasal 1 ayat 3 Undang-Undang Nomor 32 Tahun 2004 bahwa Pemerintah Daerah adalah Gubernur, Bupati atau Walikota, dan Perangkat Daerah sebagai unsur Penyelenggara Pemerintahan Daerah. Kecamatan adalah wilayah kerja camat sebagai perangkat daerah kabupaten dan daerah kota dimana dalam pelaksanaan tugasnya memperoleh pelimpahan sebagian wewenang Bupati atau Walikota untuk menangani sebagian urusan otonomi daerah disamping menyelenggarakan tugas umum pemerintahan. Kecamatan Pamulang Kota Tangerang Selatan terletak di Timur Kabupaten Tangerang dengan luas wilayah $\pm 2.778 \mathrm{Ha}$ terdiri dari tanah darat $\pm 2.286 \mathrm{Ha}$, tanah sawah $502 \mathrm{Ha}$, letak ketinggian dari permukaan laut 2000m.

Jarak dari Ibukota Kabupaten Tangerang 50km, dan Ibukota Provinsi Banten $\pm 98 \mathrm{~km}$ dan ke Ibukota Negara $1 \mathrm{~km}$, yang dihubungkan oleh jalan negara/provinsi/kbupaten. Adapun batas-batas Kecamatan Pamulang adalah sebagai berikut:

- $\quad$ Sebelah Barat berbatasan dengan Kecamatan Serpong

- $\quad$ Sebelah Timur berbatasan dengan Sawangan, Depok

- Sebelah Utara berbatasan dengan Kecamatan Ciputat

- $\quad$ Sebelah Selatan berbatasan denan Kecamatan Sawangan, Depok

Kecamatan Pamulang sangat berkembang pesat, dikatakan cukup berkembang karena dengan adanya pembangunan yang sangat cepat mulai dari infrastruktur samapai dengan persiapan sumberdaya manusia yang menunjang majunya perkembangan Kota Tangerang Selatan dan secara kebetulan kantor Walikota Tangerang Selatan sementara berada di wilayah Kecamatan Pamulang. 


\section{Struktur Organisasi dan Uraian Kerja}

Struktur organisasi merupakan suatu hal yang berperan penting di dalam kelangsungan dan keberhasilan suatu instansi atau pemerintahan. Dengan adanya struktur organisasi, maka tiap individu dalam instansi dapat bekerja sama dengan baik juga dapat bekerja secara efektif dan efisien. Dengan adanya pembagian tugas di dalam organisasi diharapkan akti vitas atau pekerjaan dari masing-masing bagia tugas Kecamatan Pamulang dapat terkoordinir, terarah dan saling menunjang sehingga dapat mencapai tujuan yang ditetapkan instansi.

Dalam struktur organisasi mencerminkan hubungan antara fungsi yang satu dengan fungsi yang lainnya. Struktur organisasi yang digunakan harus didasarkan pada sistem prosedur kerja. Sebaliknya sistem dan struktur organisasi harus menunjukkan pembagian tugas dan mempermudah sistem prosedur kerja.

Selain itu struktur organisasi yang baik harus bersifat fleksibel dan dapat disesuaikan dengan perkembangan tanpa mengganggu kelancaran organisasi. Apabila suatu ketika trjadi perkembangan, maka struktur organisasi dapat ditinjau kembali. Peninjauan itu dimaksudkan untuk melihat apakah struktur organisasi tersebut masih sesuai dengan keadaan atau harus dilakukan perubahan. Untuk memperlihatkan struktur organisasi, biasanya disusun bagan yang menggambarkan tingkat kepemimpinan dari suatu organisai secara formal dan membantu menefinisikan secara tepat tentang wewenang, tugas, dan tanggung jawab dalam instansi perusahaan. Berikut in adalah bagan dari struktur organisasi pada Kecamatan Pamulang Kota Tangerang Selatan: 


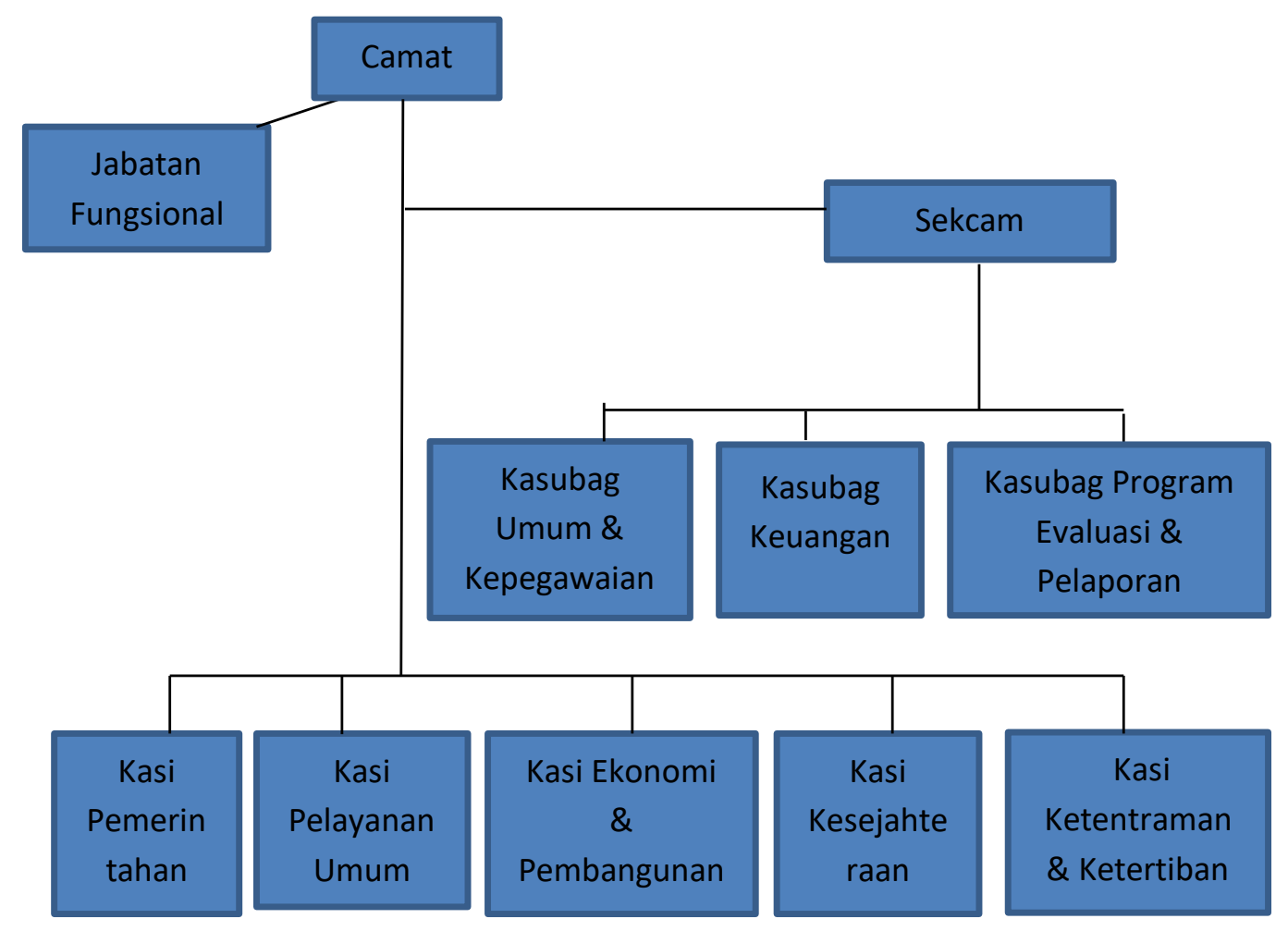

\section{Pembahasan dan Hasil Praktek Kerja Lapangan}

Setelah melakukan praktik kerja lapangan di Kantor Kecamatan Pamulang, penulis membahas tentang prosedur pengelolaan surat untuk memperlancar proses penyampaian informasi pada Kantor Kecamatan Pamulang.

Pada saat melakukan praktik kerja lapangan penulis ditempatkan pada bagian Umum dan Kepegawaian. Penulis ditempatkan pada bagian loket penerimaan surat. Dari data yang didapat dari Sub Bagian Umum dan Kepegawaian Kantor Kecamatan Pamulang, pencatatan surat masuk di Kantor Kecamatan Pamulang menggunakan buku agenda dan lembar disposisi sedangkan untuk surat keluar hanya menggunakan buku agenda surat keluar.Untuk lebih jelasnya masing-masing akan dijelaskan di bawah ini.

\section{Buku Agenda}

Buku agenda di Kantor Kecamatan Pamulangada dua jenis yaitu buku agenda surat masuk dan buku agenda surat keluar. Buku agenda surat masuk digunakan untuk mencatat semua surat yang masuk di Kantor Kecamatan Pamulang (termasuk surat undangan). Begitu juga dengan buku agenda surat keluar digunakan untuk mencatat semua surat yang dikeluarkan atau yang dikirim oleh Kantor Kecamatan Pamulang, baik itu surat dinas maupun surat undangan yang dikeluarkan atau dikirim.. Untuk lebih jelasnya mengenai format buku agenda surat masuk dan buku agendar surat keluar dapat dilihat di bawah ini. 
Format Buku Agenda Surat Masuk

\begin{tabular}{|c|c|c|c|c|c|c|c|}
\hline No & $\begin{array}{l}\text { Tanggal } \\
\text { agenda }\end{array}$ & $\begin{array}{c}\text { Tanggal } \\
\text { surat }\end{array}$ & Nomor surat & $\begin{array}{l}\text { Asal } \\
\text { Surat }\end{array}$ & Perihal & $\begin{array}{c}\text { Jadwal } \\
\text { Kegiatan }\end{array}$ & $\begin{array}{c}\text { Disposisi } \\
\text { kepada }\end{array}$ \\
\hline 435 & $\begin{array}{l}02 / 05 / 201 \\
6\end{array}$ & $\begin{array}{l}30 / 04 / 201 \\
6\end{array}$ & $\begin{array}{l}\text { 005/352/pem } \\
b\end{array}$ & SETDA & $\begin{array}{l}\text { Penyusun } \\
\text { an } \\
\text { laporan } \\
\text { realisasi } \\
\text { fisik } \\
\text { keuangan } \\
\text { pelaksana } \\
\text { an APBD } \\
\text { Kouta } \\
\text { Tangsel }\end{array}$ & $\begin{array}{l}\text { Rabu,3- } \\
\text { 05- } \\
2016 . \\
\text { Pukul } \\
13.00 . \\
\text { restaura } \\
\text { nt Telaga } \\
\text { Seafood }\end{array}$ & $\begin{array}{l}\text { KSB. } \\
\text { Keuanga } \\
n \quad \text { agar } \\
\text { hadir } \\
\text { mewakili }\end{array}$ \\
\hline
\end{tabular}

Keterangan: Buku agenda surat masuk yaitu buku yang digunakan untuk mencatat atau mendaftar surat yang masuk di Kantor Kecamatan Pamulang. Buku ini berisi kolom-kolom yang harus diisi sesuai dengan keterangan yang ada pada kolom. Keterangan yang harus diisi pada kolom antara lain :

1) Nomor, diisi dengan nomor agenda.

2) Tanggal agenda, diisi dengan tanggal pada saat menerima surat

3) Tanggal surat, diisi tanggal yang tertera pada surat.

4) Nomor surat, diisi nomor surat yang tertera pada surat yang diterima.

5) Asal surat, diisi instansi yang mengirim surat tersebut.

6) Perihal, diisi isi ringkas dari surat yang diterima.

7) Jadwal kegiatan, diisi dengan tanggal dan waktu kegiatan berlangsungnya suatu kegiatan.

8) disposisi kepada, diisi keterangan kepada bagian mana surat itu harus diteruskan atau ditangani.

Format buku agenda surat keluar

\begin{tabular}{|l|l|l|l|l|l|l|l|}
\hline No & Tgl agenda & Tgl surat & Nomor surat & $\begin{array}{c}\text { Tujuan } \\
\text { surat }\end{array}$ & Perihal & $\begin{array}{l}\text { Tembusan } \\
\text { surat }\end{array}$ & Ket \\
\hline $\begin{array}{l}34 \\
0\end{array}$ & $30 / 4 / 2016$ & $\begin{array}{l}28 / 04 / 201 \\
6\end{array}$ & $\begin{array}{l}700 / 340-K e c . \\
\text { Pm/ }\end{array}$ & $\begin{array}{l}\text { Disdukca } \\
\text { pil }\end{array}$ & $\begin{array}{l}\text { Permohon } \\
\text { an blanko } \\
\text { KK dan dikota } \\
\text { KTP }\end{array}$ & $\begin{array}{l}\text { Kasi } \\
\text { Palt, Setda } \\
\text { Tangsel }\end{array}$ & $\begin{array}{l}\text { Pemd } \\
\text { Tang }\end{array}$ \\
\hline
\end{tabular}

Tabel 3.2 sumber : sub bagian umum dan kepegawaian kantor kecamatan pamulang tahun 2016

Keterangan: Buku agenda surat keluar yaitu buku yang digunakan untuk mencatat atau mendaftar surat yang dikeluarkan oleh Kantor Kecamatan Pamulang. Buku ini berisi kolom-kolom yang harus diisi sesuai dengan 
keterangan yang ada pada kolom. Keterangan yang harus diisi pada kolom antara lain :

1) Nomor urut

2) Tanggal agenda, diisi kapan surat di agenda

3) Tanggal surat, diisi dengan tanggal waktu surat dibuat

4) Nomor surat, diisi dengan no surat keluar yang keberapa

5) Tujuan surat, diisi dengan kepada instansi mana kita mengirim surat

6) Perihal, diisi isi ringkas surat yang akan dikirimt

7) Tembusan surat, diisi kepada siapa saja surat itu dikirim

8) Keterangan, diisi keterangan dengan surat tersebut apabila diperlukan.

\section{Lembar Disposisi}

Lembar disposisi secara umum berisi informasi nonverbal untuk diterjemahkan secara seksama dan ditindaklanjuti. Disposisi merupakan petunjuk singkat tentang tindak lanjut(penyelesaian) terhadap suatu urusan atau surat masuk. Disposisi dibuat oleh pimpinan untuk staf atau bawahan sesuai dengan bidang keahlian atau kewenangannya. Tujuan pembuatan disposisi ialah agar staf dapat menindaklanjuti atau menyelesaikan suatu urusan atau surat masuk sesuai dengan yang dikehendaki oleh pimpinan. Tindak lanjut dapat berupa surat balasan, tindakan-tindakan lain dalam rangka menyelesaikan urusan tersebut.

Sebelum diserahkan kepada pimpinan, surat masuk terlebih dahulu dikendalikan oleh bagian administrasi dan diberi lembar disposisi. Di sini lembar disposisi dibuat rangkap.

3. Pengisian lembar disposisi yang menyangkut masalah pengagendaan seperti surat dari siapa, no surat, tanggal surat, diterima tanggal, no agenda ,perihal surat dan data-data tentang surat dilakukan oleh bagian administrasi. Selanjutnya pimpinan mendisposisikan siapa yang diberi tugas atau tanggung jawab untuk menindaklanjuti, serta bagaimana instruksi-instruksinya.

\section{Prosedur Pengelolaan Surat Masuk Pada Kantor Kecamatan Pamulang}

Pengelolaan surat masuk dan surat keluar pada Kantor Kecamatan Pamulang Kota Tangerang Selatan dilakukan oleh pengurus surat di Sub Bagian Umum dan Kepegawaian. Prosedur pengelolaan surat masuk dan keluar pada Kantor Kecamatan Pamulang Kota Tangerang Selatan sebagai berikut : (Sub Bagian Umum dan Kepegawaian Kantor Kecamatan Pamulang, 2016). 
1. Prosedur Pengelolaan Surat Masuk

Prosedur pengelolaan surat masuk pada Kantor Kecamatan Pamulang Kota Tangerang Selatan terdiri atas :

a. Menerima surat, yakni surat yang datang melalui kurir atau pos diterima oleh Sub Bagian Umum dan Kepegawaian.

b. Membuka surat, yakni surat dibuka sesuai dengan kriteria surat, yaitu surat masuk penting dan surat masuk biasa.

c. Menilai surat, yakni surat dinilai untuk menentukan mana surat yang penting dan mana surat rutin/biasa serta mana yang surat undangan.

d. Mencatat surat, yakni mencatat pada buku agenda dan pada lembar disposisi rangkap dua. Pada lembar disposisi diisi keterangan-keterangan sebagai berikut : surat dari instansi mana, nomor surat, tanggal terima surat, tanggal surat, no agenda dan perihal. Kemudian untuk kolom diposisinya akan diisi oleh pimpinan.

e. Memfotokopi surat, setelah surat dicatat pada buku agenda dan lembar disposisi, kemudian surat tersebut di fotokopi, dan dijadikan satu dengan surat asli beserta lembar disposisinya.

f. Setelah surat difotokopi kemudian oleh bagian umum surat masuk tersebut diserahkan kepada Sekretaris Camat untuk diberikan kepada pimpinan/camat. Setelah surat tersebut dibaca oleh pimpinan,maka pimpinan akan memberikan disposisi ke bagian mana surat tersebut perlu diteruskan. Pada bagian ini terlihat jelas bahwa prosedur pengelolaan surat disini bertujuan untuk mempercepat proses penyampaian informasi dikalangan sub-sub bagian yang bersangkutan dengan isi surat yang dimaksud.

g. Setelah surat masuk diketahui oleh Camat dan sudah diteruskan kepada bagian yang dituju,surat masuk tersebut dikembalikan lagi ke bagian umum untuk dicatat di buku agenda pada kolom "disposisi kepada" ke bagian mana disposisi surat tersebut diteruskan.

h. Setelah disposisi surat dicatat pada buku agenda kemudian surat yg asli dan lembar disposisi yang putih dijadikan satu untuk kemudian diberikan kepda disposisi surat yang dimaksud (Sub Bagian). Dan copyan surat beserta lembar disposisi yang warna merah dijadikan satu untuk arsip.

i. Sebelum copyan surat di arsip terlebih dahulu meminta paraf pada disposisi surat (Sub Bagian yang bersangkutan) sebagai bukti bahwa surat telah diterima. Lalu setelah diparaf surat masuk tersebut di arsip oleh bagian umum dan kepegawaian. 


\section{Prosedur Pengelolaan Surat Keluar Pada Kantor Kecamatan Pamulang}

Prosedur pengelolaan surat keluar dilaksanakan secara sentralisasi melalui unit Kearsipan di Sub Bagian Umum dan Kepegawaian yang terdiri atas :

a. Pembuatan konsep surat, yakni pembuatan konsep surat dimaksudkan supaya dalam pengetikan tidak terjadi kesalahan tujuan, isi, ataupun maksud dari penulisan surat tersebut.

b. Persetujuan konsep, dimaksudkan untuk megetahui apa yang akan diketik sudah mendapatkan persetujuan oleh Pimpinan.

c. Pengetikan surat, yakni setelah mendapat persetujuan dari Pimpinan maka surat tersebut diserahkan pada bagian pengetikan dan diteliti tentang kesempurnaan surat tersebut.

d. Penandatanganan surat, setelah diketik surat kemudian diserahkan kepada Pimpinan atau pejabat yang berwenang untuk dimintakan tanda tangan.

e. Pencatatan surat, yakni surat dicatat pada buku agenda surat keluar yang digunakan untuk menyimpan arsip

f. Pemberian cap dinas, setelah surat ditandatangani kemudian dicap untuk menjelaskan keberadaan suatu organisasi.

g. Penyampulan, selanjutnya yaitu penyampulan surat dengan dimasukkan ke dalam amplop pengiriman.

h. Pengiriman, apabila langkah-langkah di atas sudah dilakukan dengan baik dan seksama, kemudian surat dikirim melalui pos atau kurir.

\section{Cara Mengarsip Surat Pada Bagian Umum dan Kepegawaian Pada Kantor}

\section{Kecamatan Pamulang}

Dari hasil penelitian yang didapat pada Sub Bagian Umum dan Kepegawaian, sistem penyimpanan surat yang digunakan di Kantor Kecamatan Pamulang yaitu menggunakan sistem klasifikasi dalam bentuk numerik atau biasa disebut juga sistem penyimpanan arsip menurut nomor persepuluhan atau sistem klasifikasi desimal. Sistem penyimpanan arsip menurut nomor persepuluhan berarti surat yang dibuat atau diterima oleh suatu organisasi telah dibuatkan nomor persepuluhan tertentu untuk setiap masalah tertentu sehingga setiap masalah yang memiliki nomor persepuluhan yang sama akan disimpan pada tempat yang sama. Biasanya akan disusun penggolongan angka menjadi tiga golongan, yaitu: 
1) 10 golongan besar yang disusun dari $000,100,200,300,400,500$ dan seterusnya sampai dengan 900

2) Golongan lebih kecil yang disusun dari 10, 20, 30, 40, 50 dan seterusnya sampai dengan 90

3) Golongan terkecil yang disusun dari angka 1, 2, 3, 4, 5 dan seterusnya sampai dengan $9 ; 1$.

\section{Kendala-Kendala Yang Muncul Saat Pengelolaan Surat Pada Kantor Kecamatan Pamulang}

Adapun kendala-kendala yang muncul pada saat pengelolaan surat antara lain:

1. Pengelolaan surat masuk pada Kantor Kecamatan Pamulang kurang efisien karena harus melalui beberapa meja terlebih dahulu baru akan sampai kepada Bapak Camat. Pengelolaan ini dapat dipercepat hanya dengan melalui dua meja yaitu ketika surat diterima oleh bagian penerimaan surat yang berada di loket surat tersebut di catat pada buku agenda dan dibubuhi lembar disposisi, kemudian di gandakan. Dan setelah surat tersebut digandakan dapat langsung diserahkan kepada Sekretaris Camat untuk diserahkan kepada Bapak Camat sehingga tindak lanjut surat masuk tersebut untuk diteruskan kepada kasubag ataupun kasi-kasi yang ada hubungannya dengan isi surat tersebut dapat dilakukan dengan cepat dan juga dapat lebih efektif dan efisien.

2. Petugas pengelola surat pada Kantor Kecamatan Pamulang kurang bertanggung jawab dalam menjaga surat-surat yang disimpan sehingga banyak pegawai yang meminjam surat tanpa sepengetahuan petugas pengelola surat ketika petugas pengelola surat sedang tidak ada di tempat.

3. Proses peminjaman arsip yang dilakukan oleh beberapa pegawai pada Kantor Kecamatan Pamulang masih kurang bertanggung jawab yaitu dengan mengambil sendiri surat yang sudah diarsipkan.

\section{PENUTUP}

\section{Kesimpulan}

Dalam hal ini penulis akan mengemukakan kesimpulan yang diperoleh dari uraian pada pembahasan bab-bab sebelumnya dan berdasarkan hasil kerja lapangan yang dilakukan pada Kantor Kecamatan Pamulang. 
1. Prosedur pengelolaan surat masuk dan keluar pada Kantor Kecamatan Pamulang bisa dikatakan baik dan lancar, akan tetapi kurang efektif dan efisien dikarenakan pegawai yang mengelola surat hanya satu orang (pengelola tunggal). Prosedur pengelolaan surat masuk pada Kantor Kecamatan Pamulang terdiri atas : 1) menerima surat; 2) membuka surat; 3) menilai surat; 4) mencatat surat; 5) penandatanganan surat; 6) mengarahkan surat dan; 7) penyimpanan surat. Sedangkan untuk prosedur pengelolaan surat keluar pada Kantor Kecamatan Pamulang terdiri dari : 1) pembuatan konsep surat; 2) persetujuan konsep surat; 3) pengetikan surat; 4) penandatanganan surat; 5) pencatatan surat; 6) pemberian cap dinas 7) penyampulan surat; 8) pengiriman surat dan; 9) penyimpanan. Sedangkan cara mengarsip surat pada Kantor Kecamatan Pamulang yaitu menggunakan sistem penyimpanan klasifikasi dalam bentuk numerik atau biasa disebut dengan sistem klasifikasi desimal. Bentuk-bentuk kode numerik yang digunakan antara lain misalnya : 000 Umum, 100 Pem-an, 300 Politik, 400 Mantib-umum, 400 Kesra, 500 Perencanaan, 600 PU danTenaga, 700 Pengawasan, 800 Kepegawaian, 900 Keuangan.

2. Pengelolaan surat masuk pada Kantor Kecamatan Pamulang terlalu banyak melalui beberapa meja atau orang, sehingga tidak efektif dan efisien. Jadi surat akan sampai ke Bapak Camat bisa sore harinya. Dan untuk penyelesaian tindak lanjut surat tersebut oleh masing-masing bagian menunggu keesokan harinya lagi setelah surat turun dari Bapak Camat dan oleh unit pengolah isi disposisi ditulis keterangannya pada buku agenda surat masuk dan setelah itu baru akan di sebarkan ke masing-masing bagian yang bersangkutan dengan isi surat tersebut.

3. Para pegawai dalam meminjam surat kurang bertanggung jawab dengan mengambil sendiri surat ketika petugas pengelola surat sedang tidak berada di tempat.

\section{Saran}

1. Prosedur pengelolaan surat masuk pada Kantor Kecamatan Pamulang dapat dipersingkat hanya melalui dua meja atau dua orang, sehingga surat masuk akan cepat sampai kepada Camat saat itu juga dan akan mendapatkan tindak lanjut oleh masingmasing bagian yang bersangkutan hari itu juga.

2. Hendaknya di ruangan loket penerimaan surat masuk disediakan juga mesin fotocopy sehingga ketika ada surat masuk setelah dicatat pada buku agenda dan lembar disposisi dapat langsung diagendakan ditempat itu juga, tanpa harus berpindah ke meja atau ruangan yang satu nya lagi hanya untuk menggandakan surat. 
3. Sebaiknya ketika ada pegawai yang meminjam surat dibubuhi lembar peminjaman arsip rangkap 3, lembar pertama disimpan pada foder tempat surat yang dipinjam, lembar kedua diberikan kepada peminjam surat dan lembar ketiga disimpan oleh petgas pengelola surat sebagai bahan pengingat kalau surat tersebut sedang dipinjam.

4. Petugas arsip (pengolah) harus lebih teliti dan kreatif dengan cara melakukan pengecekan setiap surat masuk dan keluar seperti mendata semua surat yang masuk sesuai pokok bidang yang dituju, dan mengecek setiap surat yang akan dikirim seperti apakah nomor surat sudah diberikan, semua itu agar pengelolaan surat menyurat dapat berjalan dengan baik tanpa ada kesalahan.

5. Petugas pengelola surat harus selalu melakukan kontrol terhadap para pegawai yang masih membawa surat yang dipinjam yang seharusnya surat tersebut harus segera dikembalikan ke petugas pengelola surat untuk diarsipkan, serta harus dilaksanakan penataan arsip sesuai prosedur yang telah ditetapkan, sehingga apabila suatu saat surat tersebut dibutuhkan, maka surat tersebut dengan mudah untuk diketemukan.

\section{DAFTAR PUSTAKA}

Amsyah, Zulkifli. 2005. Manajemen Kearsipan. Jakarta : Gramedia Pustaka Utama

Arikunto, Suharsimi. 2006. Prosedur Penelitian Suatu Pendekatan Praktek. Yogyakarta: Rineka Cipta.

Atmosudirjo, Prajudi. 2001. Kesekretariatan dan Administrasi Perkantoran. Yogyakarta : Ghalia Indonesia

Barthos, Basir. 2009. Manajemen Kearsipan. Jakarta : Bumi Aksara

Basuki, Solistyo. 2005. Manajemen Kearsipan Modern. Jakarta : Gramedia Pustaka Utama

Gie, The Liang. 2003. Kamus Administrasi Perkantoran. Yogyakarta : Nurcahaya

Sopyan, Lis. 2005. Teknik dan Cara Penulisan Surat Menyurat. Jakarta : Visipro

Sugiarto, Agus. 2005. Manajemen Kearsipan Modern. Yogyakarta : Gava Media 
Silmi, Sikka Mutiara. 2008. Panduan Menulis Surat Lengkap. Yogyakarta : Absolut

Syamsi, Ibnu. 2008. Sistem dan Prosedur Kerja. Jakarta : Bumi Aksara

Tedjasutisna, Ating. 2000. Administrasi Kantor. Bandung : Armico

Wursanto, Ignatius. 2003, Kearsipan I. Yogyakarta : Kanisius

https://www.google.co.id+makalah+pengelolaan + surat + masuk + dan + keluar 